\title{
The Fireman's Rule: Defining Its Scope Using the Cost-Spreading Rationale
}

The fireman's rule bars tort claims by firefighters and police officers against persons whose negligence or recklessness causes the fire or other hazard that injures the officer. ${ }^{1}$ Three rationales serve as the foundation for the rule. The first rationale is based on the principle of assumption of risk, under which recovery in tort is barred when the officer voluntarily encounters a particular hazard. The second rationale derives from the officer's assumption of duties or the foreseeable risks of employment. The third is a cost-spreading rationale, under which recovery in tort is barred by the availability of a statutory compensation scheme. In conjunction with these rationales, the rule only bars actions for imjuries caused by the misconduct that prompted the officer's presence at the scene. ${ }^{2}$ An mjury that oceurs independently of the misconduct to which the officer responds is outside the scope of the rule and the officer will be able to proceed in tort.

In three recent decisions, the California Supreme Court faced the complexities posed in determining the scope of the fireman's rule. ${ }^{3}$ While the court's decisions have reinforced the idea that injuries caused by independent acts of misconduct fall outside the rule, the development of this concept hints at future inconsistency. Specifically, while legislative directive as well as public poliey mandate that intentionally inflicted imjury not be shielded by the fireman's rule, the court has not yet faced this issue and it is unclear what rule the court will announce and what reasoning it will employ. The court nnay simply declare all intentional wrongs to be independent acts of misconduct and thus place all intentional wrongdoers beyond the protection of the fireman's rule. Alternatively, the court may wish to examine further the rationales on which the rule is based in order to distinguisl between different types of intentional conduct, and to decide whether to treat some intentional conduct the same as neghigent and reckless conduct.

1. Walters v. Sloan, 20 Cal. 3d 199, 571 P.2d 609, 142 Cal. Rptr. 152 (1977).

2. Id at $202 \mathrm{n} .2,571$ P.2d at $611 \mathrm{n} .2,142$ Cal. Rptr. at 154 n.2. See also Lipson v. Superior Court, 31 Cal. 3d 362, 369, 644 P.2d 822, 826, 182 Cal. Rptr. 629, 633 (1982) (fireman's rule does not apply to injury caused by landowner's misrepresentation of hidden hazards at scene of fire).

3. Walters v. Sloan, 20 Cal. 3d 199, 571 P.2d 609, 142 Cal. Rptr. 152 (1977); Hubbard v. Boelt, 28 Cal. 3d 480, 620 P.2d 156, 169 Cal. Rptr. 706 (1980); Lipson v. Superior Court, 31 Cal. 3d 362, 644 P.2d 822, 182 Cal. Rptr. 629 (1982). 
Although a judicial declaration that all intentional wrongs are to be classified as imdependent misconduct offers a compelling simplicity, this classification is unconvincing because the test for independent misconduct looks only to the subjective anticipations of the officer. Since this analysis fails to examine the tortious quality of the wrongdoer's conduct-that is, whether it is negligent, reckless, foreseeably injurious intentional, or intentionally injurious-it fails to distinguish intentional misconduct from unintentional wrongs and provides no basis for classifying all imtentional wrongs as independent 1misconduct. Instead of this approach, this Comment suggests that in order to distinguish intentional misconduct from other wrongs, the court must first recognize that the dependent/independent test will result in the classification of some intentional wrongs as dependent misconduct. Accordmgly, if courts are to avoid applying the fireman's rule to shield intentionally injurious acts, and to do so in a doctrinally consistent manner, they must reexamine the rationales offered in previous decisions for distinguishing among different types of dependent misconduct.

Specifically, this Comment argues that the fireman's rule is best supported by the cost-spreading rationale. The fireman's rule reflects the judicial determination that the public has become a self-insurer of its own wrongs. To identify the proper scope of this rule, it becounes necessary to consider exactly what conduct is insurable and what harins the public compensation scheme intends to anticipate. Using the policies behind insurance and workers' compensation as guidelines, and examining the probability of injury inhering in different qualities of wrongful conduct, this Comment urges that the firenan's rule bar recovery for all imjuries caused by dependent misconduct, except in those imstances when the wrongdoer's conduct was intentionally injurious, as opposed to merely foreseeably injurious.

Part I of the Comment presents the California Supreine Court cases on the fireman's rule. Part II analyzes the most recent fireman's rule decision and indicates how the court may use that decision to classify all intentional harms directed at public officers ${ }^{4}$ as independent misconduct not shielded by the fireman's rule. Part III shows that the two rationales that forn the dependent/independent test, and upon which the supreme court has largely based its analysis of the fireman's rule, do not help explain why the rule should not shield intentionally mjurious conduct from tort liability.

Part IV then turns to the third rationale, that of cost-spreading. This Comment argues that the cost-spreading rationale, by considering what conduct can be insured against and what conduct should be

4. For the purpose of this Comment, "public officers" will include both firefighters and police officers. 
redressable in tort, enables a court to determine which intentional acts the fireman's rule will shield. Applying this rationale, this Part concludes that the parameters of the fireman's rule should be drawn to shield misconduct that lias the foreseeable effect of injuring a public officer, but the rule should not shield intentional misconduct that is purposefully inflicted to injure him. In short, the fireman's rule should shield all dependent misconduct that does not ineet an intentionally injurious standard. Finally, Part V proposes a coinprehensive test to impleinent this analysis.

\section{The Case Law}

The fireman's rule originally rested upon the fact that firemen responding to a fire were characterized as entrants on land, ${ }^{5}$ to whoin landowners owed a low duty of care. ${ }^{6}$ Thus, an injured firenan generally could not sue the landowner. In Califorina, however, distinctions in the duty of care owed an entrant on the landowner's property were abolished by the landinark case of Rowland $v$. Christian.$^{7}$ Rowland abolished distinctions in the duty of care owed an entrant based on his status and instead imposed a general duty of reasonable care toward any entrant. ${ }^{8}$ To the extent that the fireman's rule bars tort recovery because of the plaintiff's status as a police officer or firefighter, regardless of the nature of the landowner's conduct, it is at odds with the holding in Rowland. Nevertheless, a decade after Rowland, the California Supreme Court in Walters v. Sloan ${ }^{9}$ chose not only to retain the

5. Today, most jurisdictions still classify public officers as bicensees, although some regard them as invitees or as sui generis. See Annot., 86 A.L.R.2d 1205, 1210-12 (1962) \& Latcr Case Service at 418, 419-20 (1979 \& Supp. 1982) (firefighters); id. at 1223-24 \& Later Case Service at 424-25 (1979 \& Supp. 1982) (police officers). But cf. RESTATEMENT (SECOND) OF TORTS § 345(2) (1965) (treatimg public officers as invitees only when they enter land held open to the public).

6. Pennebaker v. San Joaquin Light \& Power Co., 158 Cal. 579, 587-88, 112 P. 459, 463 (1910). But cf. 2 F. HARPeR \& F. JAMES, THE LAW OF TORTS $\$ 27.14$, at 1501-05 (1956) (citing cases that support the rule but arguing that protection afforded a police officer should be based on the special case, not on the analogy to invitation or license).

7. 69 Cal. 2d 108, 443 P.2d 561, 70 Cal. Rptr. 97 (1968).

8. Id. at 119,443 P.2d at 568, 70 Cal. Rptr. at 104 .

The Illinois Supreme Court seemed to indicate in Dini v. Naiditch, 20 IIl. 2d 406, 170 N.E.2d 881 (1960), that it would adopt a rule of reasonableness even in the case of firefighters. Id. at 416 17,170 N.E.2d at 885-86. The decision has subsequently been explained, however, as establishing a duty of care to prevent "injury to firemen which might result from a cause independent of the fire but [to create] no duty to prevent injury resulting from the fire itself." Court v. Grzelinski, 72 Ill. 2 d 141, 147-48, 379 N.E.2d 281, 283 (1978).

9. 20 Cal. 3d 199, 202, 571 P.2d 609, 610-11, 142 Cal. Rptr. 152, 153-54 (1977). See also Giorgi v. Pacific Gas \& Elec. Co., 266 Cal. App. 2d 355, 72 Cal. Rptr. 119 (1st Dist. 1968) (adopting the fireman's rule); Solgaard v. Guy F. Atkinson Co., 6 Cal. 3d 361, 491 P.2d 821, 99 Cal. Rptr. 29 (1971) (fireinan's rule rationales do not extend to a doctor injured while treating aecident victims due to the neghigence of the victim's employer). 
fireman's rule, which had hitherto applied only to firefighters injured by a defendant's negligence, but also to extend it to police officers as well.

\section{A. Walters}

The defendants in Walters were parents who had knowledge that their minor daughter was hosting a party at their home and was serving alcohol to her friends. Guests at the party attacked and injured Officer Walters when he attempted to arrest a drunk and disorderly minor. Walters sued, alleging that the parents had caused his injury by allowing their daughter to serve alcohol to such a large number of guests. The trial court sustained the parents' demurrer based on the fireman's rule. The supreme court affirmed. In his opinion for the majority, which upheld the fireman's rule in spite of its incongruence with Rowland, Justice Clark stressed that the rule should be retained because of the contmuing importance of the doctrines of assumption of risk and cost-spreading. ${ }^{10}$

The Walters court first observed that "one who has knowingly and voluntarily confronted a lazard cannot recover for injuries sustained thereby." 11 The court identified this principle as fundainental to a number of tort doctrines imcluding the satisfaction of duty to warn, nullification of the duty of care, comparative negligence, and assumption of risk. ${ }^{12}$ Thus, the officer was barred from bringing a tort action because he knowingly and voluntarily confronted the negligently created risk.

The second argument supporting the fireman's rule in Walters was a public policy argument that officers "cannot complain of negligence in the creation of the very occasion for [their] engagement." 13 The thrust of this argument is cost-spreading. Its rationale hes in the fact that the officer is provided with a tax supported salary, workers' compensation, and special public servant benefits. ${ }^{14}$ This compensation covers injuries sustained on the job that can be attributed to the acts of neghigence that any member of the public may foreseeably commit. To the extent that the officer is protected by this comprehensive scheme a tort recovery would be duplicative, would do away with the efficiency

10. 20 Cal. 3d at 204-05, 571 P.2d at 612-13, 142 Cal. Rptr. at 155-56.

Today most jurisdictions accept the fireman's rule and preclude liability for the public's negligent acts that imjure these officers. See cases cited in Giorgi v. Pacific Gas \& Elec. Co., 266 Cal. App. 2d 355, 357-58, 72 Cal. Rptr. 119, 121 (1st Dist. 1968).

11. 20 Cal. 3d at 204, 571 P.2d at 612 , 142 Cal. Rtpr. at 155.

12. Id. The court refers to "contributory" rather than "comparative" negligence.

13. Id. at 205, 571 P.2d at 612, 142 Cal. Rptr. at 155 (quoting Krauth v. Geller, 31 N.J. 270, 274, 157 A.2d 129, 131 (1960)).

14. 20 Cal. 3d at 205-06, 571 P.2d at 612-13, 142 Cal. Rptr. at 155-56. 
advantage of the statutory scheme, and would be burdensome on both the courts and imdividuals. ${ }^{15}$

A corollary to this public policy argument is that officers are already compensated for the risks attending their jobs. In essence, it is their duty to confront hazardous situations. From this notion emerges a third possible argument supporting the fireman's rule: the officer, upon acceptance of employment, assumes the duties and foreseeable risks of that einployment.

Although the court in Walters found the defendants shielded from liability by the firenan's rule, it noted that the rule would not necessarily apply to all mjuries sustamed by a police officer or firefighter while on duty. Instead, the rule only applies to injuries caused by the same event to which the officer responds. Thus, said the court by way of illustration, a police officer who is struck by a speeding vehicle while ticketing an illegally parked car may sue the speeder, whose action represents independent misconduct not protected by the fireman's rule. The owner of the parked car, however, is shielded by the rule. ${ }^{16}$

\section{B. Hubbard v. Boelt}

Hubbard v. Boelt ${ }^{17}$ gave the California Suprene Court its second recent opportumity to consider the fireman's rule. Hubbard involved a police officer who was injured in an automobile crash following a highspeed chase with a reckless driver. Officer Hubbard sued Boelt, alleging that Boelt's recklessness had caused the officer's injuries. The trial court held that the suit was barred by the fireman's rule. The appellate court reversed, holding that the fireinan's rule was limited to situations involving passive neghigence and did not shield reckless conduct from tort liability. ${ }^{18}$ The policy considerations behind the rule, said the appellate court, did not justify immunizing a defendant from liability for "willful, reckless and unlawful acts."19

15. Id.

16. Id. at $202 \mathrm{n} .2,571$ P.2d at $611 \mathrm{n} .2,142$ Cal.Rptr. at $154 \mathrm{n} .2$.

17. 28 Cal. 3d 480, 620 P.2d 156, 169 Cal. Rptr. 706 (1980).

18. 162 Cal. Rptr. 349, 351 (4th Dist.), rev'd, 28 Cal. 3d 480, 620 P.2d 156, 169 Cal. Rptr. 706 (1980).

19. Id.

The decision also concluded that the defendant violated statutes that the legislature had fashioned in order to protect policemen as well as other citizens. Thus, when the reckless speeder violated these statutes, he breached his duty to protect the officer. Id.

The concurring opinion by Justice Staniforth, which was grounded in part on the need to deter reckless conduct, stated:

Society's absolute need to deter reckless and wanton injury as a matter of sound public policy outweighs any countervailing need to "spread the loss." The "fireman's rule" . . . is defensible where passive negligent conduct is to be balanced against an enlightened desire to allocate loss to the broadest base ... yet it cannot be defended here . . . . Extending the rule of Walters $v$. Sloan ... to Boelt's conduct would fly in the face of 
The supreme court affirmed the trial court's decision, thus extending the fireman's rule to reckless conduct. The court responded to three arguments made by the plaintiff Hubbard. ${ }^{20}$ First, the plaintiff argued that the fireman's rule did not apply to reckless conduct. The majority opinion cited the rationales relied upon in Walters and held that those principles apphied with equal force whether the hazard results from a citizen's recklessness or negligence. In situations of recklessness as well as negligence, the court concluded, the officer voluntarily encounters hazards as part of his duties for whicl he is presumably adequately compensated through salary and workers' coinpensation benefits. ${ }^{21}$

Second, Officer Hubbard atteinpted to avoid the fireman's rule by citing to dictum in Walters that the rule does not apply to injuries caused by an event independent of that to which the officer responded. Thus, the policeman argued that the defendant's reckless flight was an imdependent cause of his injury and was separate from the original negligent act of speeding. While reiterating the inapplicability of the fireinan's rule to injuries caused by independent acts, the court rejected Hubbard's contention that his claim came within this exception. ${ }^{22}$ Rather, the five member majority held that his injuries resulted froin

sound public policy favoring detcrrence of lawbreakers by the threat or imposition of sanctions.

Id. at 352 (citations omitted) (Staniforth, J., concurring).

The dissent of Justice Cologne argued that the test for imposition of the fireman's rule set out in Walters demanded that the rule be extended to cover recklessness. Justice Cologne observed that despite the different quality of the defendant's actions in Hubbard, an officer in the course of his employment encountered a known risk and was entitled to workers' compensation for the resulting mjury. Thus he saw no reason to distingnish Walters. Id. at 355-57 (Cologne, J., dissenting).

20. 28 Cal. 3d at 485,620 P.2d at 159,169 Cal. Rptr. at 709.

21. Id. at $484-85,620$ P.2d at $158-59,169$ Cal. Rptr. at 708-09.

22. Id. at $486-87,620$ P.2d at 159,169 Cal. Rptr. at 709 . The dissent would have found the fireman's rule mapplicable under the independent risk doctrine. See id. at 487-88, 620 P.2d at 160-61, 169 Cal. Rptr. at 710-11 (Tobriner, J., dissenting).

Courts of other jurisdictions liave followed this reasoning. In Trainor v. Santana, 86 N.J. 403, 432 A.2d 23 (1981), the defendant, after being stopped by a police officer, allegedly attempted to drive off with the officer's arm caught in the car door. The officer freed himself, but was struck by the car. The trial court ruled that the fireman's rule was inapplicable. The New Jersey Supreme Court agreed stating:

[T] he rule would preclude recovery by a police officer only for acts of ordimary negligence which create the occasion for a police officer's presence at the place where he is mjured. It could not be asserted as a defense where, as here, after the officer arrived at the scene and the defendant was aware of his presence, the defendant committed additional and subsequent acts of negligence which directly caused the officer's injuries. 86 N.J. at 407,432 A.2d at 25 (emphasis added).

For support, the court cited Justice Tobriner's dissent in Hubbard. Thus, New Jersey courts, which provided the impetus for California's adoption of the fireman's rule with Krauth v. Geller, 31 N.J. 270, 157 A.2d 129 (1960) and subsequently relied on the analysis in the California Supreme Court's Walters decision to extend the rule to police officers in Berko v. Freda, 172 N.J. Super. 436, 412 A.2d 821 (Law Div. 1980), would disapprove of Hubbard because the driver's 
the continuous response of an officer in pursuit of a speeding offender. ${ }^{23}$ Third, the court dismissed the officer's argument that certam statutes, ${ }^{24}$ which Boelt's flight violated, set up a duty of care towards the officer. The majority instead decided that these statutes were designed to protect the public and were not intended to protect police officers acting in an official capacity. ${ }^{25}$

subsequent acts occurred only after he was aware of the officer's presence and were therefore considered to be independent risks.

Both the majority and dissent in Hubbard relied extensively on Holden v. Chunestudey, 101 Cal. App. 3d 959, 161 Cal. Rptr. 925 (3d Dist. 1980), which held that the fireman's rule applies to recklessness. Id at 960, $161 \mathrm{Cal}$. Rptr. at 925-26. In Holden a defendant recklessly drove off the road and struck a tree. The officer imvestigated, slipped and fell, and suffered injuries. The $H u b$. bard dissent distinguished Holden in that the recklessness in Holden occurred entirely before the officer arrived, and in fact provided the occasion for the officer's presence. In Hubbard, the recklessness oceurred after the officer arrived, and in fact was in response to the officer's arrival. Tobriner thus argued that extension of the rule is not warranted by Holden. $28 \mathrm{Cal}$. 3d at 489 n.1, 620 P.2d at 161 n.1, 169 Cal. Rptr. at 711 n.1 (Tobriner, J., dissenting). See also Note, Hubbard $v$. Boelt: The Fireman's Rule Extended 9 PEPPERdINe L. REv. 197, 224-30 (1981) (arguing for the independent act approach); Note, Assumption of the Risk and the Fireman's Rule, 7 WM. MITCHELL L. REV. 749 (1981) (urging that the fireinan's rule slould not apply mechanically, but rather, that each case must be examined to determine whether the officer assumed the particular risk involved).

The Hubbard majority based their argument on a different premise. In their estimation the quahity of the defendant's action is almost irrelevant. The test inherited froin Walters instead focuses entirely on the officer, and the benefits he receives. He acts voluntarily and knowingly in the face of patent risk and receives compensation regardless of the tortious quality of the defendant's behavior. Hazards are necessarily a part of the officer's position, regardless of an individual defendant's actions. Thus, the timing and direction of the defendant's actions do not lielp distinguish recklessness from negligence. $28 \mathrm{Cal}$. 3d at 485, 620 P.2d at 158-59, 169 Cal. Rptr. at 708-09.

23. $28 \mathrm{Cal}$. 3d at 486-87, 620 P.2d at 159, 169 Cal. Rptr. at 709.

24. CaL. Penal CODE $\S 148$ (West 1970) (prolibiting willful resistance to or delay of arrest); Cal. Penal Code $\$ 834$ a (West 1970) (imposing duty on arrestee to refrain from using force or any weapon to resist arrest); CAL. VEH. CODE $\$ 2800.1$ (West Supp. 1982) (prohibiting willful disregard of officer's siren and lights and flight therefroin).

25. $28 \mathrm{Cal}$. 3d at 485-86, 620 P.2d at 159, $169 \mathrm{Cal}$. Rptr. at 709. This Comment does not consider whether the statutes involved in Hubbard confer a duty that extends to protect public officers. Walters, 20 Cal. 3d at 206-07, 571 P.2d at 613, 142 Cal. Rptr. at 156; Hubbard, 28 Cal. 3d at 485-86, 620 P.2d at 159, 169 Cal. Rptr. at 709, and courts of other jurisdictions feel that the legislature did not intend such protection. The minority, the appellate court, and other jurisdictions disagree. See id. at 490, 620 P.2d at 162, 169 Cal. Rptr. at 711-12; Hubbard v. Boelt, 162 Cal. Rptr. at 351; Annot., 86 A.L.R.2d 1205, 1218-20 (1962) \& Later Case Service at 418, $422-23$ (1979) (discussing cases holding that a statute or an ordinance provides or does not provide a duty to protect firefighters); id. at 1224-25 \& Later Case Service at 90 (Supp. 1982) (discussing cases holding that a statute or ordmance provides or does not provide a duty to protect police officcrs). But see CAL. Crv. CODE \& 1714.9, 1982 Cal. Legis. Serv. 1367-68 (West), which reverses Hubbard on the issue of whether the statutes cited by Officer Hubbard and violated by Boelt were intended to protect the officer from injury. The statute does not affect the case to the extent that it merely lolds that reckless misconduct is shielded by the fireman's rule. Where the reckless conduct occurs after the arrival of the public officer and violates a statute prohibiting resistance or disobedience to an officer, however, it appears that notwithstanding Hubbard the defendant will no longer be able to prevail by claiming the proteetion of the fireman's rule. See also infra note 41 and Author's Postscript. 


\section{Lipson}

The most recent supreme court pronouncement on the fireman's rule came in Lipson v. Superior Court. ${ }^{26}$ Firefighter Lipson responded to a call from a chemical manufacturing plant to contain a boilover. Lipson alleged that upon arrival at the plant, the plant operator denied that the boilover involved any toxic substance. In reality, however, the boilover contained toxic chemicals that severely injured the fireman. Lipson asserted that the defendant's misrepresentation caused his injuries since he was misled as to the true nature of the boilover and thus was unable to adequately protect himself. ${ }^{27}$ Lipson also alleged that because of the maintenance of an abnormally dangerous activity, the defendant was strictly liable for any resulting injury. ${ }^{28}$

The defendant noved for summary judgment arguing that whether or not a misrepresentation had taken place, a civil action was barred by the fireman's rule. The trial court deined the motion. Subsequently, an appellate court issued an alternative writ and thus held that the fireman's rule barred an action for misrepresentation.

The supreme court in Lipson lield that the fireman's rule does not preclude a claim for either negligent or intentional misrepresentation of the hazards facing a public officer. Chief Justice Bird wrote for the majority ${ }^{29}$ that California cases have consistently indicated that some injuries are outside the ambit of the fireman's rule despite the quality of the tortious act. ${ }^{30}$ The court observed that:

the fireman's rule has never been construed as shielding a defendant from liability for acts of misconduct which are independent from those which necessitated the summoning of the fireman. The rule has only been applied to prohibit a fireman from recovering for mjuries caused by the very misconduct which created the risk which necessitated his presence. $^{31}$

Lipson recognized that, under earlier cases, independent misconduct is found when a public officer is injured by a member of the public while responding to a matter unrelated to the misconduct of the tortfeasor. ${ }^{32}$ Citing the hypothetical of the policeman struck by a

26. 31 Cal. 3d 362, 644 P.2d 822, 182 Cal. Rptr. 629 (1982).

27. Id. at 365,644 P.2d at 824,182 Cal. Rptr. at 631 .

28. Id. at $366,644 \mathrm{P} .2 \mathrm{~d}$ at $824,182 \mathrm{Cal}$. Rptr. at 631 .

29. Two justices, in an opinion written by Justice Mosk, concurred in the result but objected to several hypotheticals posed by the Chief Justice on the grounds that the examples were misleading as well as unnecessary to the decision. Id. at 379-80, 644 P.2d at 833, 182 Cal. Rptr. at 640 (Mosk, J., concurring and dissenting).

30. Id. at 369,644 P.2d at 826,182 Cal. Rptr. at 633.

31. Id. (emphasis in original) (citations omitted).

32. See, e.g., Spargur v. Park, 128 Cal. App. 3d 469, 472-73, 180 Cal. Rptr. 257, 258-59 (2d Dist. 1982) (firenan's rule will not bar suit for injury caused by misconduct other than that demanding the officer's presence); Malo v. Willis, 126 Cal. App. 3d 543, 548, 178 Cal. Rptr. 774, 777- 
speeder while ticketing an illegally parked car-where the cause of injury is different from the officer's reason for being at the scene-the supreme court held that a misrepresentation of the nature of a boilover posed a hazard different from the non-toxic spill to which the firefighter had responded. ${ }^{33}$ Since the resulting imjuries occurred independently of the firefighter's reason for being present, the fireman's rule did not bar hability.

The court also drew upon one of the Walters/Hubbard rationales, the voluntary encounter rationale, in reaching its decision to disallow the fireman's rule as a bar to hability in the case of a misrepresentation. ${ }^{34}$ As the court observed, the fireman's rule is based primarily upon the doctrine of assumption of risk. Thus, "one who has knowingly and voluntarily confronted a hazard cannot recover for injuries sustamed thereby."35 Yet the court reasoned that instead of assuming every possible risk they may encounter, firefighters only assume those risks that can be reasonably anticipated. ${ }^{36}$ While the firefighter may anticipate the collapse of a burning wall, he unay also be expected to rely on the owner's word regarding the existence or absence of unique or hidden hazards that inust be faced. The court concluded that when the officer is misled as to the nature of the dangers presented, he cannot be said to have assumed the risk that resulted in his injury, and therefore the voluntary encounter rationale relied upon in Walters and Hubbard is mapplicable. ${ }^{37}$

Finally, the court indicated that public policy supported the finding that the fireman's rule should not allow a landowner who makes

78 (4th Dist. 1981) (fireman's rule does not bar suit brought by police officer mjured while stopping defendant's auto because of defendant's inexperience with manual transmission since the injurious conduct was not the cause of the officer's presence).

33. 31 Cal. 3d at 368, 371, 644 P.2d at 826, 828, 182 Cal. Rptr. at 633, 635 (citing Walters, 20 Cal. 3d at 202 n.2, 571 P.2d at 611 n.2, 142 Cal. Rptr. at 154 n.2).

34. 31 Cal. 3d at 370-71, 644 P.2d at 827-28, 182 Cal. Rptr. at 634-35.

35. Id. at 370, 644 P.2d at 827, 182 Cal. Rptr. at 634 (quoting Walters, 20 Cal. 3d at 204, 571 P.2d at 612, 142 Cal. Rptr. at 155 ).

36. 31 Cal. 3d at 371, 644 P.2d at 828, 182 Cal. Rptr. at 634-35.

37. Id. at 370,644 P.2d at 827,182 Cal. Rptr. at 634.

The court also considered claims that a summary judgment motion should have been granted and that the manufacturer should have been held strictly liable for engaging in an abnormally dangerous activity. The summary judgment appeal was rejected because the manufacturer could not conclusively show that a misrepresentation had not taken place. Id. at 377-78, 644 P.2d at 832, 182 Cal. Rptr. at 638-39.

In considering the claim of strict hability, the court used the same test for identifying independent and dependent risks as it had used in considering the claim for inisrepresentation. Id. at 376-77, 644 P.2d at 831-32, 182 Cal. Rptr. at 638 . Thus, a defendant injured by the hazard to which he is summoned will not be able to mamtain a civil action even if an abnornally dangerous activity is mvolved. An action for strict liability will be appropriate, however, if the abnormally dangerous activity injures a public officer independently of the misconduct to which he or she originally responded. $I d$. 
misrepresentations of the nature of a fire to escape civil liability. Since firefighters must rely upon the landowner's cooperation in figliting a fire, the court found that public policy demanded that sucl misconduct should be compensible through the tort system. In reaching this result the court relied upon a recently enacted civil statute, whicl states that notwithstanding existing case law to the contrary, any person who willfully harms a public officer in the performance of his duties will be responsible for damages except to the extent of the officer's comparative fault. ${ }^{38}$

II

\section{Alternatives For APPLyINg the FiremaN's Rule AFTER LIPSON}

As the California Supreme Court noted, most of the Lipson decision is in complete accord with the preexisting California case law on the fireman's rule. Ever smce Walters, California courts have stated that the fireman's rule only shields the defendant from liability for acts that furmsh the occasion for the officer's presence. ${ }^{39}$ In Lipson, since the toxic nature of the boilover was misrepresented, the hazard that mjured the public officer was different from the one to which he believed he was responding. As Lipson correctly lield, such an act, whether negligent or intentional, is not shielded by the fireman's rule. ${ }^{40}$

Commentators and the supreme court itself have held this to be a determination of whether the injuries were caused by the misconduct that prompted the officer's presence, or whether the injury was caused by independent misconduct. ${ }^{41}$ Lipson held that the fireman's rule does

38. CaL. Lab. Code $\$ 3852$ (b), 1982 Cal. Legis. Serv. 741 (West), which states that: Notwithstanding statutory or decisional law to the contrary, any person who knows or should have known of the presence of a peace officer or firefighter is responsible not only for the results of the person's willful acts, bnt also for any injury occasioned to the peace officer or firefighter by the person's want of ordinary care or skill in the management of the person's property or person, which occurs after the person knows or should have known of the presence of the peace officer or firefighter, except to the extent that the comparative fault of the peace officer or firefighter contributes to the imjury.

39. Hubbard v. Boelt, 28 Cal. 3d 480, 484, 620 P.2d 156, 158, 169 Cal. Rptr. 706, 708 (1980); Malo v. Willis, 126 Cal. App. 3d 543, 547, 178 Cal. Rptr. 774, 777 (4th Dist. 1981); Holden v. Chunestudey, 101 Cal. App. 3d 959, 961, 161 Cal. Rptr. 925, 926 (3d Dist. 1980).

40. 31 Cal. 3d at 370, 644 P.2d at 827, 182 Cal. Rptr. at 634. See also Comment, Negligence Actions by Police Officers and Firefighters: $A$ Need for a Professional Rescuers Rule, 66 CALIF. L. REV. 585, 600-01 (1978) [hereinafter cited as Comment, Rescuers Rule] (using the independent/ dependent analysis to define the scope of the fireinan's rule). See infra note 43.

41. But see CaL. Civ. Code $\$ 1714.9,1982$ Cal. Legis. Serv. 1367-68 (West). This statute provides that an independent risk also exists in those limited circumstances involving misconduct that either occurs or continues after the arrival of the officer, injures the officer, and violates a statute that was imtended to protect the officer from such an injury. An excellent example of this type of independent risk is a speeding motorist whose reckless driving becomes fiight from a pursuing officer. Injuries sustained while giving chase must be classified as the product of an in- 
not apply to independent misconduct regardless of whether the underlying conduct was neghient, reckless, or intentional. Therefore, if the court finds the misconduct to be independent, the quality of the defendant's acts will not matter, and injuries resulting from these acts will be redressable in tort.

Where the cause of injury is determined to be dependent, however, the court inust conduct a further imquiry into the quahty of the defendant's actions. In Hubbard, for exainple, the court found that a police officer who pursued a reckless driver was hurt by the saine reckless misconduct that prompted his presence. The court then had to consider whether reckless conduct should be treated differently than negligent conduct. The court decided that since the officer voluntarily confronted the risk as part of his job and would receive the saine anount of workers' compensation no inatter how he received the imjury, there was no reason to differentiate between neghigence and recklessness. ${ }^{42}$

The conclusion that appears from the case law is that the Califormia Supreme Court has formulated a two-step test. ${ }^{43}$ The first step, deinonstrated by the holding in Lipson, determines whetlier dependent or independent misconduct caused the public officer's mjury. If the imjury was independently caused, the fireman's rule will be inapphicable and the analysis ends. If, on the other hand, the court finds the cause to be dependent, as was the case in Hubbard, it will have to proceed to the second step of the inquiry; namely, whether the defendant's conduct is of a quahity that should be shielded by the fireinan's rule.

This inquiry into the applicability of the fireman's rule is inade inore complex by the fact that acts which intentionally injure a police officer or firefighter, whether they are dependent or independent, cannot be shielded by the rule. While both fundamental fairness and a recognition of the deterrent function of tort law lead to this result, ${ }^{44}$ it is

dependent risk, since the Legislature has determined that statutes prohibiting resistance, flight, or disobedience to an officer's orders are ineant to protect public officers. See also W. Prosser, HANDBOOK ON THE LAW OF TORTS 190-97 (4th ed. 1971). See infra Author's Postscript.

42. $28 \mathrm{Cal} .3 \mathrm{~d}$ at $484-85,620$ P.2d at 158-59, 169 Cal. Rptr. at 708-09.

43. See Comment, Rescuers Rule, supra note 40 , where the commentator also uses a two-step process and proposes a test similar to the one set out in this Comment. The Rescuers Rule Comment argues that independent risks should be distinguished froin dependent risks, with the fireman's rule only barring liability for the latter. The Rescuers Rule Counment then suggests that severe dependent risks, identified with the lielp of the concepts of extraordinary risk and especially blameworthy conduct, can be distinguished to allow a private cause of action. Id. at 600-02.

44. The policy calling for more severe treatment of intentional harms is illustrated by the fact that far greater liability is imposed on the intentional tortfeasor than on the negligent one. See W. Prosser, supra note 41, at 30-31. The public policy against intentional harm is also manifest in the area of criminal law, where defenses tend to be much inore difficult to establish. Id. at ch. 4. For a discussion of the relationship between the fireman's rule and the need for deterrence of certain imtentional conduct, see infra notes 99-101 and accompanying text. 
also dictated by legislative policy. As noted already, section 3852(b) of the California Labor Code provides that one who intentionally injures a police officer or firefighter is civilly liable to that person. ${ }^{45}$ Putting aside moral or deterrence concerns, then, legislation leaves no doubt that the fireman's rule cannot shield intentional wrongdoers from liability to public officers.

Thus, while the Lipson decision did not change the fireman's rule, it is clear that after Lipson the court needs to liave at its disposal, for the second stage of the two-step test, a rationale for excluding intentionally imjurious acts from the fireman's rule's shield. The question remaining after Lipson is how the supreme court will fill this need. There seems to be two possible alternatives: either the court will employ the rationales of Walters and Hubbard to distinguish intentionally injurious conduct from all other misconduct, or it will flatly decide that all types of intentional wrongs constitute independent acts regardless of the conduct that prompted the officer's presence.

While fairness, deterrence, and the legislature's directive indicate that intentionally injurious conduct must not be shielded by the fireinan's rule, these important concerns do not suggest which of the two alteruatives the court will cloose. The most likely possibility after Lipson seems to be that the court will forego the rationales of Walters and Hubbard and will classify intentionally injurious conduct as independent acts. In fact, one lower court has already reached this conclusion in a case involving an intentional assault. ${ }^{46}$ The reasoning that leads to the conclusion that the intentionally injurious conduct is an independ-

45. Such a policy is further demonstrated by penal statutes that make it a crime to assault either a police officer or a firefighter. CAL. PenAl CODE $\$ \S 241,243$ (West Supp. 1982). A criminal statute will provide a civil remedy if the statute was enacted to prevent the injury that the plaintiff suffered, and the plaintiff belongs to the class of individuals protected by the statute. W. Prosser, supra note 41 , at 192-96. Clearly, statutes that make it a separate crime to assault a public officer, as opposed to an ordinary citizen, were enacted for the public officer's benefit. See People v. Corey, 21 Cal. 3d 738, 581 P.2d 644, 147 Cal. Rptr. 639 (1978).

46. Krueger v. City of Anaheim, 130 Cal. App. 3d 166, 181 Cal. Rptr. 631 (4th Dist. 1982). Krueger involved a city security guard at a California Angels baseball game who was injured when he attempted to eject a spectator who scaled the fence and ran across the field during the game. The officer alleged that in the ensuing scuffle the defendant intentionally inflicted injury by kicking and striking and was thus liable for assault and battery. The court held that the fireinan's rule was inapplicable to intentional assault because such conduct is not dependent on the original risk and the officer cannot be said to assume suclı risks. Id. at $171,181 \mathrm{Cal}$. Rptr. at 635 .

This Comment does not discuss the Krueger scenario because it presents such a borderline case. Specifically, when an officer tries to eject a trespasser, does lie anticipate the possibility of intentional injury? Under the test proposed by this Comment, if he does not anticipate the intentional injury, the risk should be declared independent and the action sliould lie. If he does anticipate a struggle, the risk will be dependent and the fireman's rule might apply. As will be discussed in Part IV, however, the defendant's intentionally injurious misconduct places him outside the protection of the fireman's rule and therefore allows the officer to proceed in tort. Thus, although this Comment disagrees with the reasoning of Krueger, its result seems correct. 
ent cause of injury suggests that such conduct is not the hazard to which the officer is responding. ${ }^{47}$ Furthermore, the doctrime of assumption of risk is not, for reasons of public policy, applicable to intentionally injurious conduct directed at the officer. ${ }^{48}$ This too suggests that the cause of the injury will be determined to be an independent one, since an independent cause of injury, by definition, is not assumed by the public officer. ${ }^{49}$

As will be shown in Part III, the rationales that the court relied on in Walters and Hubbard, and that form the basis of the dependent/ independent distinction, do not provide a reason for classifyimg all $\mathrm{m}$ tentional misconduct as independent acts. In other words, some hazards caused by intentional misconduct are dependent on those to which the officer responds, and thus, judging from the case law to date, deserve to be shielded by the fireman's rule. Simce these rationales and therefore the dependent/mdependent distimction do not provide a reason for classifymg all imtentional misconduct as independent acts, this Comment will explore the third of the Walters/Hubbard rationales, the cost-spreading rationale, to discover a new explanation of the fireman's rule that does offer principled parameters for its application.

\section{III \\ The DePendent/INDEPENDENT TeST}

The voluntary encounter rationale and the duty rationale form the basis for the Califorma Supreme Court's test for identifying independent and dependent acts. The test considers whether the officer was injured by the same conduct that occasioned his presence. ${ }^{50}$ There are two considerations that go into determining whether an injury's cause is imdependent or dependent. First, the court apphes the voluntary encounter rationale and examines what risks the officer subjectively anticipated. Then the court applies the duty rationale and considers what job the officer was attempting to perform. If the officer voluntarily encountered the hazard that injured him while attempting to eliminate it as part of his job, then the cause of injury will be considered dependent. If, however, the officer attempted to confront one hazard and was mjured by a causally separate one, then the injury is the product of an independent act. Accordingly, this Coinunent will exainine each of these two rationales separately to show that they neither help im classifying all imtentional misconduct as independent nor adequately distim-

\footnotetext{
47. Id. at 170, 181 Cal. Rptr. at 634.

48. See id. at 170-73, 181 Cal. Rptr. at 633-35; CAL. LAB. CodE § 3852(b).

49. Krueger, 130 Cal. App. 3d at 171-72, 181 Cal. Rptr. at 635.

50. Lipson, 31 Cal. 3d at 369, 644 P.2d at 826, 182 Cal. Rptr. at 633.
} 
guish among dependent acts to determine which should be shielded by the fireman's rule.

\section{A. The Voluntary Encounter Rationale}

The voluntary encounter rationale arises out of the doctrine of assumption of risk and suggests that an officer who knowingly and voluntarily encounters hazards should not be allowed to sue in tort for mjuries that are the product of that hazard. Thus the voluntary encounter rationale does not apply to independent acts because these, by definition, are acts of misconduct other than those to which the officer intends to respond and so are expressly not assumed. ${ }^{51}$

\section{The Rationale's Relationship to Assumption of Risk}

The fireman's rule cases have analogized the voluntary encounter rationale to assumption of risk. ${ }^{52}$ Arguably, it might be possible to graft the doctrine of assumption of risk onto this rationale in order to classify all types of intentional wrongs as independent causes of injury. Since the doctrine of assumption of risk does not apply to intentionally injurious acts directed at officers, ${ }^{53}$ the court could similarly determine that the fireman's rule does not bar liability for intentionally injurious misconduct. While the voluntary encounter rationale is derived from the doctrine of assumption of risk, however, the two differ in substantial ways. Making the two parallel in order to add to the fireman's rule the limitation pertaining to intentional conduct would necessarily incorporate the full reach of assumption of risk as it applies to negligence and recklessness as well.

According to Prosser, assumption of risk applies when "the plaintiff, aware of a risk already created by the negligence of the defendant, proceeds voluntarily to encounter it." ${ }^{34}$ Assumption of risk bars the plaimtiff from recovering for his injuries. ${ }^{55}$ In the context of the fireinan's rule, the voluntary encounter rationale does not bar recovery but does limit the remedies available. The officer is denied recourse in tort, but may still obtain compensation and disability benefits.

In addition, the assumption of risk doctrine as apphied in Califorma involves asking whether the plaintiff acted reasonably in confronting the risk. Only in those situations where a plaintiff is judged to have acted reasonably does the doctrine bar recovery in tort. ${ }^{56}$ Yet a

51. Id. at 370, $644 \mathrm{P} .2 \mathrm{~d}$ at $827,182 \mathrm{Cal}$. Rptr. at 634.

52. Id. at 370-71, 644 P.2d at 828, 182 Cal. Rptr. at 634-35.

53. See sources cited supra note 48.

54. W. Prosser, supra note 41 , at 440.

55. Id.

56. Li v. Yellow Cab Co., 13 Cal. 3d 804, 824-25, 532 P.2d 1226, 1240-41, 119 Cal. Rptr. 858, 
reasonableness limitation does not seem feasible to apply to a police officer or firefighter whose very job is to face risks that reasonable citizens choose to avoid. What is reasonable for a public officer to face is entirely different from what is reasonable for a private citizen. Furthermore, as is discussed im the conclusion to this section, the fact that an officer is duty bound to face risks flies in the face of the premise that the officer will be able to choose a reasonable course of action. ${ }^{57}$

In light of these differences, it does not seem appropriate to equate the voluntary encounter rationale with assumption of risk by grafting on the limitation regarding imtentional conduct. Rather, the voluntary encounter rationale as it is now applied seems well suited to the fireman's rule. The voluntary encounter rationale is not an absolute doctrine but a factor for a court to consider. It looks only at an officer's subjective anticipation regarding the encountered hazard. That an officer suffers mjury from an anticipated risk is only a factor pointing to the conclusion that civil liability should be barred. None of the court's decisions mdicates that sucl a conclusion mandates barring the tort claim.

\section{The Rationale's Limits}

The voluntary encounter rationale, while setting limits on who will be immune from tort liability, does not adequately restrict the scope of the fireman's rule. The rationale does help limit the fireman's rule to persons who create the risk that the officer must face, while excluding those parties who mjure an officer not confronting such a risk. Thus the rationale identifies which risks are dependent and whicls are independent. Yet the rationale focuses entirely on the actions and anticipations of the public officer and ignores the quality of the defendant's 1misconduct. The shortcoming of the voluntary encounter rationale is that it fails to distinguish among the various dependent acts that may be encountered by officers $m$ the course of their duties. Such a differentiation must be made by a court faced with the question of which types of dependent conduct the fireman's rule shields.

The voluntary encounter rationale makes the quality of the defendant's actions-whether they are neghigent, reckless, foreseeably injurious, or intentionally mjurious-irrelevant. Indeed, given the foreseeability of intentional misconduct im a public officer's line of work and the obvious risks such conduct presents, the voluntary en-

872 (1975). Where the plaintiff's actions are unreasonable the recovery, if any, is reduced according to the plaintiff's comparative negligence. Id. Since the doctrine of comparative negligence does not coine into play until after it has been decided that a plaintiff may recover, the doctrine is of no use in determining whether the fireinan's rule bars a public officer's tort action.

57. See infra notes 59-62 and accompanying text. 
counter rationale suggests that the fireman's rule should shield intentional as well as neghigent and reckless misconduct. Thus the rationale neither distinguishes among dependent acts of misconduct nor does it classify all intentional misconduct as independent risks. Since it merely considers the officer's state of mind and not the quality of the defendant's act, it does not succeed in explaiming why some intentional misconduct is not and should not be shielded by the fireman's rule.

\section{B. The Duty Rationale}

The public policy argument supporting the firennan's rule in Walters and Hubbard bars public officers froin tort recovery because they are compensated for undertaking their hazardous work. ${ }^{58}$ One element of this argument is that while public officers miglit not voluntarily confront risks, at times they must do so as part of their jobs. This is what is meant by the duty rationale. Firefighters and police officers have a legal and moral duty to protect the public and thus face hazards that the reasonable mdividual would avoid.

The duty rationale undercuts the voluntary encounter rationale because it attributes the officer's conduct to professional responsibility, not to a personal assessment of the hazards involved. The duty rationale was applied in Bilyeu v. Standard Freight Lines, ${ }^{59}$ a pre-Walters case that allowed an officer to bring a negligence cause of action agamst the wrongdoer who caused his injuries. In Bilyeu, an on-duty police officer was injured while clearing a higlwway of debris spilled from the defendant's overturned truck. The driver argued that the officer had assumed the risk of injury as a inatter of law. The appellate court disagreed, holding instead that "[the officer's] choice, being dictated by a legal and moral duty, was not voluntary within the requirements of the doctrine [of assunption of risk]."60 After Walters, Bilyeu is no longer good law. ${ }^{61}$ However, its assessinent of the conflict between duty and voluntariness reinains sound. A public officer who acts out of a legal and perhaps inoral duty cannot be said to have acted voluntarily. ${ }^{62}$

The notion of duty not only contradicts the voluntary encounter

58. Hubbard, 28 Cal. 3d at 484, 620 P.2d at 158, 169 Cal. Rptr. at 708; Walters, 20 Cal. 3d at 204, 571 P.2d at 612, 142 Cal. Rptr. at 155.

59. 182 Cal. App. 2d 536, 6 Cal. Rptr. 65 (4th Dist. 1960).

60. Id. at 545, 6 Cal. Rptr. at 70.

61. Bilyeu was decided many years before Walters and therefore did not discuss the fireman's rule. Presumably, under the Walters test, civil liability would now be precluded.

62. Historically, the cases have held that officers have a duty to arrest a person committing a misdemeanor, Dorris v. McKamy, 40 Cal. App. 267, 273, 180 P. 645, 648 (2d Dist. 1919), or a felony, Lees v. Colgan, $120 \mathrm{Cal} .262,269,52$ P. 502, 504 (1898). An officer who refuses to make such an arrest may be subject to fine and imprisonment. CAL. PeNAL CODE $\S 142$ (West 1970). 
rationale, but like that rationale it fails to suggest parameters within which the fireman's rule should apply. The duty rationale applies to any foreseeable hazard, and almost any hazard is foreseeable for firefighters and police officers. If the fireman's rule bars liability for all misconduct that requires the officer's presence in an official capacity ${ }^{63}$ then the quality of the defendant's conduct seems irrelevant. Apprehending imdividuals who attempt to intentionally harm police officers is as much a part of an officer's duty as arresting speeders. By focusing on the officer's responsibilities instead of the defendant's actions, the duty rationale, like the voluntary encounter rationale, fails to provide a clear limit to the fireman's rule.

Thus, after close scrutiny, neitlier the voluntary encounter rationale nor the duty rationale can be said to provide sufficient grounds for distimguishing among different acts that injure public officers while performing their duties. In fact, the two actually conflict when it comes to assessing voluntarmess of an officer who acts under a sense of duty. Since these rationales form the basis of the test for distimguishing dependent and independent conduct, it is clear that the dependent/independent test cannot be used to simply classify all intentionally mjurious acts as imdependent risks to which the fireman's rule does not apply. Because the dependent/independent test evaluates only what risk the officer anticipates and what job he imtends to perform, ${ }^{64}$ it provides no basis for reasoning that all intentionally injurious acts constitute independent causes of mjury. For example, when a police officer responds to a call warning of an armed guninan, the officer who responds must be said to anticipate the likelihood of serious personal injury, but nonetheless must confront the gunman im order to protect the public. In spite of the imisconduct being intentional, the cause of the mjury is clearly dependent, smce it is the same hazard as that to which the officer is responding.

Instead of taking the conceptually simple but logically untenable route of classifying all types of intentional misconduct as independent causes of mjury, this Comment suggests that some intentional misconduct must be considered dependent and thus shielded by the fireman's rule. Nevertheless, by returning to the remaining Walters/Hubbard rationale, and to the origms of the rule itself, this Comment will present another analysis of the rule that will determine what type of intentional misconduct will be shielded by the fireman's rule. This analysis will satisfy the legislative directive that the rule not shield intentionally in-

63. Hubbard, 28 Cal. 3d at 486-87, 620 P.2d at 159, 169 Cal. Rptr. at 709.

64. Thus, this Comment suggests that for purposes of the dependent/independent test, the analysis of duties should focus on the foreseeable risks facing a public officer, rather than on each individual situation the officer faces. 
jurious acts while not doing violence to the rationales on which the rule's very existence is predicated.

IV

\section{The Cost-Spreading Rationale}

The otler eleinent of Walters' and Hubbard's public policy argument is the cost-spreading rationale. Firefighters and police officers are coinpensated for their public duties. This tax-supported compensation includes salary, disability benefits, and retirement benefits. ${ }^{65}$ Compensation serves the dual function of inducing persons to undertake these hazardous jobs while spreading the costs of their injuries among the public they serve. Thus, the officers' tax-supported coinpensation program allows the public to imsure against the injuries that its officers will inevitably sustain in the performance of their duties.

This cost-spreading rationale was first suggested in a firennan's rule case by Chief Justice Joseph Weintraub of the New Jersey Supreine Court in Krauth v. Geller ${ }^{66}$ In his opinion for the majority, Weintraub wrote that "it would be too burdensome to cliarge all who carelessly cause or fail to prevent fires with the injuries suffered by the expert retained with public funds to deal with those inevitable . . . occurrences."67 While the Califormia Supreine Court quoted and relied on this cost-spreading language in its Walters opinion, the test that emerged from Walters and was applied in Hubbard and Lipson focused largely on notions of voluntary encounter and acceptance of duty. While continuing to refer to the cost-spreading rationale, the California Supreme Court has largely ignored its utility as a basis for applying the fireinan's rule. ${ }^{68}$

In Krauth, Chief Justice Weintraub's analysis noted that the public has an obligation to compensate their injured officers because the public has a capacity for carelessness that inevitably results in injuries to officers. Weintraub observed that it is inore efficient to coinpensate for these injuries through salary and benefits provided by the public ratler than through imdividual tort actions. ${ }^{69}$ Thus, the fireman's rule is based upon a public policy decision to ineet the public's obligation to its officers collectively through tax-supported compensation rather than

65. Walter, 20 Cal. 3d at 205-06, 571 P.2d at 612-13, 142 Cal. Rptr. at 155-56.

66. 31 N.J. 270, 157 A.2d 129 (1960).

67. Id. at 274,157 A.2d at 131 .

68. The cost-spreading rationale is discussed extensively in Walters, $20 \mathrm{Cal} .3 \mathrm{~d}$ at 204-06, 571 P.2d at $612-13,142$ Cal. Rptr. at 155-56, is given summary treatment in Hubbard, 28 Cal. 3d at 484,620 P.2d at 158, 169 Cal. Rptr. at 708, but is not mentioned in Lipson. This Section will show, however, that the holding in Lipson can readily be explained in terms of the cost-spreading rationale.

69. 31 N.J. at $273-74,157$ A.2d at $130-31$. 
through individual tort recoveries. ${ }^{70}$ This spreads the costs of injuries to public officers among the whole community, ${ }^{71}$ making the public in essence a self-insurer agamst those wrongs that any of its members may commit.

\section{A. Applying the Cost-Spreading Rationale}

The California Supreme Court recognizes, at least to the extent of citmg it, that the fireman's rule is a common law adjunct to the legislative self-insurance benefits of salary, disability and pension benefits paid to public officers to compensate for injuries inflicted on them by the pubhic. ${ }^{72}$ Given the existence of the statutory coinpensation scheme, tort liability must be precluded whenever the rule applies lest the pubhic pay twice for injuring its officers: once through taxes to support the statutory compensation system, and again through insurance rates increased to reflect tort judgments against individuals. The problem remains, however, of identifying what injury producing conduct is insured against by the statutory scheine, and thus what conduct is shielded by the fireinan's rule.

To answer this question, this section turns to analogies drawn from private insurance and workers' compensation for insight into what conduct the public can ordinarily insure against. In addition, this section explores the deterrent effect of tort liability for injuries to public officers. From that starting point, it addresses the relationship of the fireman's rule to neghigence, recklessness, foreseeably injurious intentional conduct and intentionally injurious conduct, and shows how the costspreading rationale provides a basis for applying the rule within the

70. 2 F. HARPER \& F. JAMES, supra note $6, \S 27.14$, at 1502-04.

71. The spreading of risks among the community is a familiar tort concept. Cf. Greenman v. Yuba Power Prods., Inc., 59 Cal. 2d 57, 377 P.2d 897, 27 Cal. Rptr. 697 (1963) (policy of riskspreading in products liability).

72. Hubbard, 28 Cal. 3d at 484, 620 P.2d at 158, 169 Cal. Rptr. at 708; Walters, 20 Cal. 3d at 205-06, 571 P.2d at 612-13, 142 Cal. Rptr. at 155-56.

The Hubbard court implied that workers' compensation provides liberal rewards. $28 \mathrm{Cal} .3 \mathrm{~d}$ at 485, 620 P.2d at 158-59, 169 Cal. Rptr. at 708-09. A workers' compensation award, however, will usually be far lower than a tort judgment. W. PROSSER, supra note 41 , at 531; 2 F. HARPER \& F. JAMES, supra note 6 , at 1502 . In addition, the coinpensation statutes cited by the court in Walters, 20 Cal. 3d at 205, 571 P.2d at $613,142 \mathrm{Cal}$. Rptr. at 156, will not fully protect an officer. For example, CAL. LAB. CODE $\$ 3212$ (West 1971) covers only hernias, leart trouble and pneumonia and thus probably does not help the officer in the case of a recklessly inflicted injury; CAL. GOv'T CODE $\$ \S 21363-21371$ (West 1978 \& Supp. 1980) apply only when the officer dies; CAL. LAB. CODE $\$ \S 4800,4850$ (West Supp. 1982) provide a maximum of one year's salary for an officer unable to work. The officer also las no chance at a pain and suffering award, which often inakes up a large portion of a tort judgment. 1 A. LARSON, THE LAW OF WORKMAN'S COMPENSATION $\S 2.40$ (1978). Yet while the compensation benefits to public officers inay be less adequate than the court inplies, criticisin of the adequacy of workers' coinpensation statutes would seem to be best directed to the legislature. 
parameters set by the dependent/independent test on the one hand and the legislature on the other.

\section{Private Insurance}

The same policy considerations that support individual private insurance coverage of negligent and reckless conduct support the application of the fireman's rule to that conduct. In California, insurance normally protects agaimst liability only for negligent and reckless acts. ${ }^{73}$ Since members of the public regularly insure themselves against negligence and recklessness, it is clear that both types of wrongs can be anticipated by the public. By the saine token, the ability to anticipate these types of wrongs and protect against thein in advance is seen when the public provides a disability and coinpensation system for its public officers. ${ }^{74}$ The fireman's rule embodies the recognition that since the public has anticipated negligent and reckless injuries to its officers and has established a scheme to offset the costs of these injuries, it should not be held doubly accountable through liability in tort.

General legislative policy would seem to argue against any anticipatory compensation system that provides benefits to public officers who are injured while confronting intentional misconduct. Thus section 533 of the California Insurance Code states that "[a]n insurer is not liable for a loss caused by the willful act of the insured."75 Yet workers' compensation statutes have traditionally covered intentional misconduct, ${ }^{76}$ evcn though it does not always provide an exclusive remedy. Thus the general policy of section 533 may appear at first glance to be overridden when it comes to identifying the types of liarm that can be compensated by a disability systein.

Nevertheless, the policy of not being allowed to insure against intentional wrongs is in actuality respected by workers' compensation. When a wrong is judged intentionally injurious (as opposed to being merely foreseeably injurious), the offender may be held civilly liable despite the availability of workers' compensation benefits. ${ }^{77}$ Thus, in these cases, although workers' compensation is available, the wrong-

73. The Insurance Code prohibits insurance for intentional miscondnct. CAL. INS. CODE $\S 533$ (West 1972). By inference, since $\S 533$ bars only intentional misconduct, negligence and recklessness may be insured against.

74. For an exainple of a court looking to the expectations of the parties in order to determine the scope of a compensation scheme, see Magliulo v. Superior Conrt, 47 Cal. App. 3d 760, 778, 121 Cal. Rptr. 621,635 (1st Dist. 1975). For commentary, see Note, Johns-Manville Prod. Corp. v. Superior Court: Intentional Aggravation of Injury as an Exception to Exclusive Workers' Compensation Remcdies, 69 CALIF. L. REv. 1230, 1242-44 (1981) [hereinafter cited as Note, JohnsManville].

75. CAL. INS. CODE $\S 533$ (West 1972).

76. See infra notes $81-83$ and accompanying text.

77. See infra notes $88-92$ and accompanying text. 
doer is not protected against personal hability. In fact, the wrongdoer will probably be fully liable for all damages and any excess recovery will be recouped by the workers' compensation fund to avoid double recovery. ${ }^{78}$ In addition, section 533 mandates that a judgment im the case of intentionally injurious misconduct will not be shielded by the wrongdoer's private insurance. Thus the sclieme of private insurance does not protect those who commit intentionally injurious acts even though workers' compensation may be available to protect their victims. By analogy, the fireman's rule, whicli sets up a public msurance system by anticipating the public's wrongs to its officers, should not shield all intentional wrongdoers from liability.

\section{Workers' Compensation}

This subsection looks to workers' compensation as a guide for the larger salary and benefit scheme that covers public officers. In California, neghigent and reckless conduct that causes a work-related employee injury is within the exclusive jurisdiction of the workers' conipensation system. ${ }^{79}$ California cases liave consistently lield that even recklessness, despite its serious nature, does not allow the employee to go outside the workers' conipensation systen and sue in tort. ${ }^{80}$ In addition, section 4553 of the California Labor Code provides that "conipensation otherwise recoverable shall be mcreased by onehalf where the enployee is injured by reason of the serious and willful misconduct" of the entployer, to a ceiling of $\$ 10,000 .^{81}$ This provision has been construed to cover sone fornis of intentional and reckless employer misconduct. ${ }^{82}$ Thus, section 4553 is the legislature's response to

78. If the injured officer recovers under both the tort judgment and workers' coinpensation, the state or compensating inunicipality should be reimbursed. See CAL. LAB. Code $\$ 3852$ (West Supp. 1982) (allowing einployer claims against third party tortfeasors); CAL. LAB CoDE \$ 3856(b) (West 1971) (allowing employer who has paid compensation to injured employee to attach lien on the einployee's judgment against the third party).

79. The California workers' compensation schene applies to any injury to a covcred employee "arising out of and in the course of the employment." CAL. LAB. CODE $\$ 3600$ (West Supp. 1981). Workers' compensation greatly aids public officers in that relief comes quickly; furtherinore, certain statutory presumptions allow more injuries to fall within the system. See, e.g., Cal. LAB. CODE § 3212 (West Supp. 1981) (presuinption that public officers wlio suffer hernias, heart trouble, and pneumonia are injured within the scope of their public activities and thus are eligible for workers' compensation). In addition, workers' compensation statutes generally do not require a showing of tortious conduct. CAL. ConST. art. XIV, § 4 (formerly art. XX, § 21, amended 1976); see also W. Prosser, supra note 41, at 531.

80. Johns-Manville Prods. Corp. v. Superior Court, 27 Cal. 3d 465, 612 P.2d 948, 165 Cal. Rptr. 858 (1980) (holding that even certaim types of intentional conduct will not justify a civil remedy where the injury is nornially covered by workers' coinpensation); Lambreton v. Industrial Accidents Comm'n, 46 Cal. 2d 498, 297 P.2d 9 (1956) (remedy for gross negligence lies within workers' compensation).

81. Cal. Lab. Code $\$ 4553$ (West Supp. 1981).

82. Johns-Manville, 27 Cal. 3d at 470-73, 612 P.2d at 951-53, 165 Cal. Rptr. at 861-63 (apply- 
the need for some "penalty" for serious employer misconduct, ${ }^{83}$ while still ensuring that the injured employee's remedy comes from the disability system.

In both Walters and Hubbard, Justice Tobriner contended in dissent that the fireman's rule was inconsistent with the existence of workers' compensation. ${ }^{84}$ Even though an einployee is injured in the course of his employment, workers' compensation permits the employee to bring an action against a third party who causes the injury. ${ }^{85}$ Justice Tobriner argued that a member of the public who negligently or recklessly mjures a policeman should be liable in tort, just as a third-party tortfeasor is liable under workers' compensation.

Tobriner's argument, lowever, is not persuasive. Rather than standing in the shoes of a third-party tortfeasor, the public stands in the shoes of the employer who operates a hazardous workplace. Three reasons can be advanced for this public-as-employer analogy. First, fire companies and police forces are created by the public to take care of those hazards that individuals inevitably create. Since the public lias no need for their services until some danger arises, there is no "workplace" for these officers except for hazardous ones. The California court recognized this in Walters when it quoted Krauth v. Geller for the proposition that "it is the fireman's business to deal with that very liazard and hence .. . he cannot complain of negligence in the creation of the very occasion for his engagement." 86 Second, Walters, Hubbard, and Lipson all make it clear that the fireman's rule will not apply to all imjuries that occur while the officer is on duty, but only to those caused by dependent acts of misconduct. In short, the dependent/independent test places the same limitations on the fireman's rule that the "arising out of and in the scope of employment" test does on workers' compensation. It limits the rule to workplace (dependent) risks, that is to inju-

ing $\S 4553$ to intentional misconduct); Magliulo v. Superior Court, 47 Cal. App. 3d 760, 778-79, 121 Cal. Rptr. 621, 635 (1st Dist. 1975) (applying \& 4553 to recklessness).

83. For a discussion of the Johns-Manville case and the policy of punitive damages as it pertains to $\$ 4553$, see Note, Johns-Manville, supra note 74 , at $1246-49$.

84. Walters, 20 Cal. 3d at 208-10, 571 P.2d at 614-15, 142 Cal. Rptr. at 157-58 (Tobriner, J., dissenting); Hubbard, 28 Cal. 3d at 491, 620 P.2d at 162-63, 169 Cal. Rptr. at 712-13 (Tobriner, J., dissenting).

85. 2 W. Hanna, California Law of Employee InJuries and Workmen's CompensaTION \$ 23.01[1] (2d ed. 1982) [hereinafter cited as W. HANNA]:

An employee who sustains injury arising out of and in the course of his or lier enployinent because of the negligence of a third party, . . . [who is] not his or lier einployer, may bring a civil action for damages against such third party in the saine manner as though his or lier injury were not work-connected. As a matter of fact, the einployee's right against the negligent third party is precisely the same as if the imjury had occurred outside the employer-employee relationship.

See also CAL. LAB. CODE $\$ 3852$ (West Supp. 1982).

86. Walters, 20 Cal. 3d at 205, 571 P.2d at 612 , 142 Cal. Rptr. at 155 (quoting Krauth, 31 N.J. at $273-74,157$ A.2d at 131). 
ries that occur while the officer faces the hazard that he was called to confront. Third, also supporting the public-as-employer analogy is the fact that the public supports the public officers' disability and compensation scheme through its tax dollars, which are the functional equivalents of the workers' compensation insurance premiums that employers pay.

Justice Tobriner's argument is correct, however, when the issue involves an officer mjured by an independent act of misconduct. Only dependent acts create the occasion for the officer's presence, so only dependent acts are part of the covered "workplace." A person who creates an mjury-causing independent hazard can thus be seen as a third party who injures an employee, and is treated analogously to a third-party tortfeasor under workers' compensation. Simce only dependent acts give rise to covered "workplace" imjuries compensable through the public officers' benefit scheine, persons who injure officers in other ways should be hable in tort for the officers' injuries.

A necessary corollary to the "covered-risk" arguinent of the costspreadimg rationale requires that conduct associated with an unacceptably high risk of mjury - that is, intentionally injurious conduct-not be covered by the public self-imsurance scheme or the fireman's rule. It has already been shown that the individual cannot insure himself agamst hability for intentionally injurious acts, even where statutory workers' compensation would ordinarily compensate an injured employee. ${ }^{87}$ It now remains to be shown, agaim using workers' compensation as a model, that the public cannot collectively insure agamst hability for intentionally injurious acts committed by its nembers.

In Johns-Manville Products Corp. v. Superior Court ${ }^{88}$ the California Supreme Court noted a trend in recent California workers' compensation cases that civil liability is not precluded where there has been intentional inisconduct. The court in Johns-Manville found that the defendant corporation had fraudulently concealed medical information from the plaintiff that mdicated that he was suffering from work-related asbestos ingestion. By inducing the employee to continue to work, Johns-Manville was found to have intentionally aggravated the disease. The court held that "in some exceptional circumstances the employer is not free from lability at law for his intentional acts even if the resulting injuries to his einployees are compensable under workers' compensation." 89 The court rehed heavily on the appellate case of Magliulo v. Superior Court, ${ }^{90}$ which held an employer hable in tort for

87. See supra note 78 and text accompanying notes 77-78.

88. 27 Cal. 3d 465, 475-76, 612 P.2d 948, 954-55, 165 Cal. Rptr. 858, 864-65 (1980).

89. Id. at 473,612 P.2d at 953,165 Cal. Rptr. at 863.

90. 47 Cal. App. 3d 760, 121 Cal. Rptr. 621 (1st Dist. 1975). 
his intentional assault of an einployee. ${ }^{91}$

Johns-Manville and Magliulo indicate that workers who are injured as a result of egregious and intentional einployer misconduct may go outside the disability systenn and sue in tort. Simce the public is treated as a self-imsurer through a statutory compensation scheme for purposes of the fireman's rule, these workers' coinpensation decisions suggest standards for what conduct should and should not be shielded from civil hability by the fireman's rule. Since most cases where a person commits an imtentionally injurious act against a public officer will involve some sort of physical assault, the Johns-Manville test of egregiousness will presumably be fulfilled. Simce the statutory coinpensation scheme does not anticipate the high risk of mjury resulting from such conduct, the public officer should not be barred from bringing a civil action for mjuries caused by intentionally injurious acts directed at the officer. ${ }^{92}$

The notion of anticipatory insurance, either individually through liability policies or collectively through a statutory compensation scheme, applies by looking to the risk that such conduct will result in some harm, rather than conduct per se. For example, in the case of the fireman's rule, the question of what injurious conduct the public must anticipate should imvolve an analysis of the probability that the public officer will suffer some injury. This analysis ınust determine wlietler the harm imvolves only a degree of risk normally associated witl the job and thus normally coinpensated for, or whether the conduct is so likely to produce injury as to warrant availability of the extraordinary remedy of a tort suit. Simce intentionally injurious acts directed at an officer are much more likely to result in soine injury to the officer than are random acts of negligence or recklessness, the risks associated with that conduct are much too great for the public to insure agamst. Negligent and reckless conduct, on the other hand, present risks of injury within the legal standard of insurability and within the scope that the public intends to insure, and so the risk and the conduct associated with it are covered. ${ }^{93}$

91. The Magliulo court argued that since the statute allows an einployee to sue a fellow employee in the case of an intentional assault, CAL. LAB. CODE $\$ 3601$ (West Supp. 1981), workers would have the expectation that employer assault should be similarly treatcd. $47 \mathrm{Cal}$. App. at 77778, 121 Cal. Rptr. at 634-35.

92. Cf. supra text accompanying notes $77-78$ (wrongdoer who commits intentionally injurious act upon a worker will be liable in tort despite the availability of workers' compensation for the victim).

93. There are indications in at least three cases that the notion of the risk associated with conduct, as opposed to the conduct alone, is what courts consider in applying the fireman's rule. See Hubbard, 28 Cal. 3d at 489 n.1, 620 P.2d at 161 n.1, 169 Cal. Rptr. at 711 n.1 (Tobriner, J., dissenting) (conjecturing that the decision in Holden was "perhaps influenced by the fact that the allegedly wanton conduct in that case had as a practical matter created no greater risk to the 


\section{Policy Concerns}

In order to be consistent with the policy choices made in relation to private imsurance and workers' compensation, the fireman's rule must preclude tort liability for dependent acts of misconduct that cause mjury to police officers and firefighters, and leave statutory benefits as the sole remedy except in cases of intentionally injurious wrong. As already noted, the California Supreme Court seeins to have recognized that the fireman's rule is a cost-spreading insurance scheme for those employment-related injuries against which the public chooses to insure. ${ }^{94}$ Since independent hazards are not employment related in that they do not provide the occasion for the officer's presence, they are not within the insured class and the wrongdoer should be accountable in tort.

Similarly, intentionally injurious acts are outside the set of insurable hazards because the risk of injury resulting is too great-in fact, a near certainty if the act is successful. Private insurance, of course, does not cover intentionally injurious acts. Workers' compensation also excludes from coverage intentional imjuries, as opposed to merely foreseeable injuries, to the employee. ${ }^{95}$ The Johns-Manville court made this distinction when it held the defendant liable for intentionally withholding the medical information that aggravated the injury, but not for the initial act of providing an unsafe workplace that had the foreseeable result of injuring the employee. ${ }^{96}$ Additionally, the statutes that make it a crime to assault a public officer support this intentionally injurious standard. ${ }^{97}$ These crimes require, in addition to the normal elements of assault and battery, the specific intent to harm a public officer acting in the performance of his duty. ${ }^{98}$

officer than would have been posed if the accident had resulted from simple negligence"); Krauth, 31 N.J. at 275,157 A.2d at 131 ("[W] here hability is found the emphasis is not upon culpability with respect to the inception of the fire but rather with respect to the other risks of injury we have described."); Jackson v. Velveray Corp., 82 N.J. Super. 469, 475, 198 A.2d 115, 118-19 (1964) (citing Krauth and holding that " $[t]$ here are certain risks inherent to firefighting . . . . Undue risk beyond these inherent hazards is something inore.").

94. See supra note 72 and accompanying text.

95. Substantial certainty will satisfy the law's requirement for intentional conduct. W. Prosser, supra note 41, at 31-32.

96. $27 \mathrm{Cal} .3 \mathrm{~d}$ at 477,612 P.2d at $955,165 \mathrm{Cal}$. Rptr. at 865 .

97. Cal. Penal Code $\$ \S 241,243$ (West Supp. 1982). See also Cal. Penal. Code $\$ 1547$ (West Supp. 1982) (providing a reward of up to $\$ 10,000$ for information leading to the arrest and conviction of an individual who assaults a police officer). See generally W. LAFAVE \& A. ScotT, Handbook on Criminal Law 602-04 (1972).

98. See, eg., People v. Henderson, 58 Cal. App. 3d 349, 358, 129 Cal. Rptr. 844, 850 (2d Dist. 1976) (quoting People v. Jones, 8 Cal. App. 3d 710, 716, $87 \mathrm{Cal}$. Rptr. 625, 629 (2d Dist. 1970)). On the relationship between specific and general intent in criminal law, see LAFAve \& ScoTT, supra note 97, at 201-02. On the relationship between knowledge and intent, see id. at 19598. 
Refusing to use the fireman's rule to bar liability in cases of intentionally mjurious conduct not only coinports with legislative directive, but it also comports with the notions of cost-spreading and deterrence. Basic to the cost-spreading rationale is the idea that the hazards that the pubhic creates are accidental and inevitable, and so the public prefers to spread the costs of compensation among the population that the officers serve as opposed to holding those responsible individually liable. Yet simce legislative intent indicates that the public's tax dollars will not be allowed to anticipate intentionally injurious wrongs, these wrongdoers should be responsible in tort.

Deterrence is another important consideration when examining the cost-spreading rationale and the larger question of what conduct the fireman's rule should cover. Tort liability not only compensates for injuries, but also attempts to deter the conduct that caused the injury. ${ }^{99}$ By allowing the public to anticipate dependent wrongs through the fireman's rule, the legislature necessarily sacrifices solne of the deterrent effect of imdividual suits. ${ }^{100}$ Yet, as shown, the insurance and workers' compensation models make a similar choice for both neghigent and reckless behavior and thus demonstrate a preference for spreading the risk over providing deterrence. ${ }^{101}$

Since both maliciousness and a high likelihood of injury are involved, the policy of deterrence supports allowing an action in tort for intentionally inflicted injuries. The deterrent value may be less important since such conduct is covered by criminal statutes ${ }^{102}$ that serve an equal, if not greater, deterrent function. Because the fireman's rule is an adjunct to the legislative compensation scheme, however, the court's determination about what conduct falls within the cost-spreading scheme of the fireman's rule controls what conduct the scheme deters.

99. W. PROSSER, supra note 41 , at 23.

100. The same observation can be made for workers' compensation in general. The level of deterrence that accompanies full payment of damages in individual suits is sacrificed in favor of an efficient and sure remedy.

101. In other situations, reckless behavior has prompted judicial and legislative responses for deterrence. In Taylor v. Superior Court, 24 Cal. 3d 890, 598 P.2d 854, 157 Cal. Rptr. 693 (1979), the defendant's habitual drunk driving led to the imposition of punitive damages. The court reasoned that this type of recklessuess was such a serious problem that a special award was necessary for the sake of deterrence. See W. PROSSER, supra note 41, at 184-85 (stating that wanton conduct and recklessness are equivalent in the eyes of the law). Similarly, CAL. LAB. CODE $\$ 4553$ (West Supp. 1982) demonstrates an intent to deter serious and willful employer misconduct. See supra text accompanying note 81 for details of this statute. The Hubbard court did not consider the lost deterrent effect of extending the fireman's rule to recklessness. One possible answer to this concern is legislative enactment of a "penalty provision" similar to CAL. LAB. CODE § 4553 . Nonetheless, if the legislative policies behind insurance and workers' compensation schemes are relevant, then in the final analysis the need for spreading the risk may outweigh the need for deterrence in the case of reckless acts.

102. See statutes cited supra note 97. 
Nevertheless, the court's only proper role is to interpret, through the fireman's rule, the scope of statutory compensation. The court should not then reweigh the legislature's decision about the value of added deterrence.

Thus a person who commits an intentionally injurious act against a public officer should not be protected by the fireman's rule, and should be held liable in tort. The fireman's rule, lowever, should apply to those situations where the defendant's conduct involves only foreseeably mjurious intentional acts. The line between intentionally mjurious and foreseeably injurious may not always be clear but, as poimted out in Johns-Manville, a difference exists.

\section{Drawing the Line between Foreseeably Injurious Intentional Conduct and Intentionally Injurious Conduct}

The cost spreading rationale supports the distimction made in Johns-Manville between foreseeably imjurious intentional conduct and intentionally mjurious conduct. Where the risk of injury is within the acceptable level-that is, the level that the public has chosen to anticipate through the statutory compensation scheme-the resultimg imjury is compensible and the fireman's rule will bar an action regardless of the specific misconduct involved. As already noted, the rationale for smgling out imtentionally injurious acts is the high likelihood that they will result in an injury to the officer. ${ }^{103}$ On the other hand, foreseeable mjury resultimg from intentional conduct presents an altogether different degree of risk in the case of a public officer. Such an injury is the result of an intentional act that necessarily presents liazards to the public officers who respond.

Arson, whicl is a foreseeably injurious act, presents an excellent example of this analysis. Altlough arson is an intentional act, the resultimg fire remains a dependent hazard even though intentionally caused, smce fightimg the fire, regardless of its origim, is what prompts the presence of the firefighters on the scene. Additionally, a fire caused by arson presents no unique liazards to the firefighter simply on account of its origim. The dangers present are those of fire, not of the imtentional act of arson. Simce these are the sort of dependent hazards the anticipation of which has given rise to publicly supported statutory benefits, the statutory compensation slould be the exclusive remedy for any resultimg injuries suffered by firefighters. The fireman's rule should therefore apply to this foreseeably mjurious intentional act and bar liability in tort.

Intentionally mjurious acts, however, present hazards that differ im

103. See supra text accompanying note 92 . 
degree of probable harm. An officer has as much control over the possibility of injury posed by a foreseeably injurious intentional act as he does over the same hazard created by negligence or recklessness. In contrast, a public officer facing intentionally injurious conduct can do little to safeguard himself short of ignoring the situation entirely. In short, the cost-spreading rationale, by examining what risks the public intends to anticipate through its compensation scheme, must consider the likelihood of injury incumbent upon different qualities of conduct. Under the cost-spreading rationale, the fireman's rule should bar a civil suit where a citizen intentionally creates a situation that foreseeably may injure an attending officer, because the probability of injury is not significantly greater than if the hazard were created by negligence or recklessness. However, since intentionally injurious conduct poses a very high probability of injury, the cost-spreading rationale, consistent with legislative directive and public policy, indicates that the fireman's rule should not bar a private suit.

If applied as suggested in this Comment, the cost-spreading rationale would shield from civil liability mjuries caused by criminal acts such as arson. The question that arises, then, is whether following the cost-spreading rationale and applying the fireinan's rule to foreseeably mjurious intentional acts but not intentionally imjurious acts does violence to notions of deterrence or fundamental fairness. This Comment argues that it does not, and maimtains that the cost-spreading rationale provides parameters for applying the rule which current doctrine cannot.

This Comment has shown that the cost-spreading rationale makes the same policy choices about fairness and deterrence for the fireman's rule that have already been made for workers' compensation and private insurance. The policy choice that has been made permits ordinary workers to sue only for injuries caused by third parties or intentionally injurious employer-caused injurics. The rationale provides a basis for applying the fireman's rule in the same fashion, since it allows public officers to sue only for independent (non-workplace) hazards and intentionally injurious acts. If this conception of the firennan's rule violates notions of fundamental fairness or deterrence, these notions are also offended by workers' compensation. Furthermore, public officers are professionals who expect hazards and are trained and employed to confront them, even though those hazards are intentionally caused. To the average employee, however, any type of intentional misconduct represents an aberrant level of risk that is neither expected nor assumed. If any individual is to be permitted to sue, the ordinary employee seems to be a more deserving plaintiff than does a trained public officer. 
In addition, the policy argunnent that prevents officers injured by neghigent or reckless conduct from suing in tort is consistent with extending the fireman's rule to foreseeably injurious but not intentionally mjurious acts. Such an extension is the result of applying the fireman's rule on a risk basis as well as on a conduct basis, thus examining not only the quality of the defendant's conduct but also the likelihood of mjury associated with that conduct. Otherwise, officers injured by similar hazards would receive different remedies solely because in one case the hazard was intentionally created and in the other it was not. Admittedly, individual officers might prefer to forego statutory benefits for the possibility of a larger tort judgment. Yet for society as a whole, it is more efficient to provide certam, rapid, and low-cost compensation through the statutory scheme. ${ }^{104}$

Finally, this Comment identifies principled limits to the apphication of the rule that comport with the statutory compensation scheme by identifying the haruns that the public anticipates. Althougl mitially it may seem unfair to compensate officers injured by foreseeably injurious intentional acts from the statutory fund, smce that forces all taxpayers to indemnify intentional wrongdoers rather than make them pay the full cost of their deeds, ${ }^{105}$ this is in fact the best place to draw the line. In the first place, taxpayers have no stronger relationship to another's neghigent or reckless acts than they do to foreseeably imjurious intentional ones. Yet applying the fireman's rule to neghigent and reckless acts and compensating the injured officers out of the statutory fund is no less indemnification of those wrongdoers. Unless fire companies and police forces become wholly private firms that bill for the full cost of a call, including compensation for the injured, soine indemnification of wrongdoers seems imevitable.

Society has clearly chosen soine level of subsidization of wrongdoers rather than liave each member of the public pay the full cost of a fire. Once the notion of subsidization is accepted, this Comment argues that the optimum level is that which results froin differentiating be-

104. These efficiency and equity advantages to "mass compensation" via a public compensation scheme, as opposed to numerous individual suits, is well documented in the literature. See, e.g., E. Chett, INJURY AND Recovery IN THE Course of EMployment ch. 9 (1961); 2 W. HANNA, supra note 85, at $\S 1.05$; INSTITUTE FOR LOCAL SELF GOVERNMENT, EQUiTY EROdED: The Disintegration of Workers' Compensation Policies 18-19 (1977).

105. Krauth, 31 N.J. at 274,157 A.2d at 131 , lield that

[p]robably most fires are attributable to negligence, and in the final analysis the policy decision is that it would be too burdensome to cliarge all who carelessly cause or fail to prevent fires with the mjuries suffered by the expert retained with public funds to deal with those inevitable, although negligently created, occurrences.

The California Supreme Court in Hubbard, 28 Cal. 3d at 484-85, 620 P.2d at 158-59, $169 \mathrm{Cal}$. Rptr. at 708-09, makes this same policy decision in the case of a police officer injured by reckless, as opposed to negligent, conduct. 
tween foreseeably injurious intentional acts and intentionally injurious conduct. Fire caused by arson presents the same risk of injury to a firefighter as does any fire caused by negligence or recklessness. ${ }^{106}$ Since the probability of injury faced is the saine as that froun a negligent or reckless fire, the firefighter should be treated similarly and so suffers no detriment by receiving statutory coinpensation. ${ }^{107}$ To the extent that the incremental costs to society are greater than if the fire were never set, the criminal justice systein is available to punish the conduct giving rise to this injury to society. Tort liability is not barred, however, where injuries are caused by either independent acts or intentionally injurious conduct: the former is not intended to be covered by the public because it is not a dependent (workplace) hazard, and the latter

106. A few cases indicate that even in situations involving the most dangerous sorts of fires the freman's rule will apply because the risks are those normally associated with a firefighter's job and are thus within his capacity to anticipate. See Lipson, 31 Cal. 3d at 371, 644 P.2d at 827-28, 182 Cal. Rptr. at 635. In Armstrong v. Mailand, 284 N.W.2d 343 (Minn. 1979), involving the explosion of a liquid propane gas tank, the court applied the fireman's rule because the risk was known to the firefighters. In Krauth, 31 N.J. at 275,157 A.2d at 131, the court applied the fireman's rule and said that "where liability is fouud the einpliasis is not upon culpability witl respect to the inception of the fire but rather with respect to the other risks of injury we have described." In Jackson v. Velveray Corp., 82 N.J. Super. 469, 475, 198 A.2d 115, 118-19 (1964), the court applied the fireman's rule in a case where a burning wall collapsed and killed a fireman, holding that "[t]he collapse of a floor, ceiling or wall of a burning building, without more, is a hazard a fireman unust ordinarily anticipate. Undue risk beyond these inherent hazards is something more. It includes hidden perils . . . and other conditions independent of the fire itself." The court also extended the reasoning of Krauth, emphasizing that the risk of injury, as opposed to culpability with respect to the imception and spread of the fire, was the determinative factor in finding liability.

These cases demonstrate that regardless of low dangerous a fire is, the fireman's rule will apply unless the officer's injuries were the result of an independent harm or intentionally injurious misconduct. The rule similarly applies regardless of the origin of the fire because causal acts alone do not create risks that are beyond the ability of the firefighter to anticipate. The notion that a fire caused by arson is somehow inherently more dangerous than a negligently or recklessly caused one, absent some additional independent harm or some intentionally injurious act, is unsupported in fact. The inherent risks of firefighting do not change according to the cause of the fire or the reason it spreads. See Jackson, 82 N.J. Super. at 475,198 A.2d at 118 . Thus no mere human agency could liave inade the liquid propane gas fire in Armstrong more dangerous than it already was. Nor can fires caused by arson be distinguished on the basis that they involve a violation of a statute. The arson statute, like the statutes cited in Walters and Hubbard, was probably not enacted for the purpose of protecting firefighters. In addition, the fatal fires in Armstrong and Jackson involved various violations of safety statutes and regulations that similarly did not allow a remedy in tort.

107. Criminal prosecution should be society's sole recourse in the case of arson. A suit against the wrongdoer to subrogate the statutory compensation fund seems inconsistent with the fireman's rule and the analysis of this Comment. If such a suit is proper in the case of intentionaI conduct, there seems no justification for not allowing similar suits in the case of negligent or reckless conduct, except for a desire to punish intentional acts. Criminal prosecution provides such punishment. Furthermore, a recovery by the fund in a suit against an intentional wrongdoer can only be premised on the fund having been depleted by a risk not meant to be covered. As this Comment has shown, however, the cost-spreading rationale favors extending the fireman's rule to foreseeably injurious intentional acts but not intentionally injurious acts. 
represents an unacceptably great and thus uninsurable risk. In neither of these two circumstances does the public intend to indemnify the wrongdoer.

\section{$\mathrm{V}$ \\ The Proposed Test}

This Comment proposes that courts apply the fireinan's rule according to a two-step test. First, the court slould determine whether or not the injury resulted from the same misconduct that prompted the officer's presence. In other words, if the officer is injured by the very hazard that lie anticipated but close to confront in the line of duty, then the cause of injury would be dependent. If the injury occurs only incidentaly to the misconduct to which the officer responded, however, then its cause would be independent. If the cause is judged to be independent, the court's consideration should end regardless of the quality of the defendant's action. Since the fireman's rule applies only to those injuries that are dependent on the presence of the officer and thus anticipated through the compensation scheine, the rule should be inapplicable to independent hazards, and the wrongdoer slould be liable.

If, on the other hand, the court finds the injury to be caused by the origmal misconduct, then the cost-spreading rationale of Walters should apply. In essence, analysis slows that the publicly supported compensation system is intended to provide the exclusive reinedy for all dependent (workplace) imjuries, except those which ineet the intentionally injurious standard of Johns-Manville. Thus, at the second tier of analysis, the fireman's rule should shield all defendants from civil hability whose conduct does not fulfill the intentionally injurious test. $^{108}$

\section{CONCLUSION}

Several recent decisions by the California Supreme Court and California appellate courts have reaffirmed the fireman's rule but have left some doubts about the consistency of the approach in those cases. While it is clear that suits by public officers alleging intentionally inju-

108. This Comment does not purport to apply this same analysis to volunteer or paid-call firefighters or to voluntary auxiliary police officers. While many of the arguments in this Comment would apply with equal force to the issue of shielding those wlio injure nonprofessionals (e.g., nonprofessionals who voluntarily face risks encountered to the lime of duty and who receive workers' compensation for work-related injuries) it is possible that because of a lack of traming and experience, nonprofessiouals face substantially greater risk of mjury than professionals when confronted by similar lrazards. If so, as a matter of public policy, society might wish to distinguish between nonprofessionals and professionals in applying the fireman's rule. For a recent case holding that paid-call firefighters are covered by the fireman's rule, see Baker v. Superior Court, 129 Cal. App. 3d 710, 181 Cal. Rptr. 311 (4th Dist. 1982). 
rious wrongs will not be shielded by the rule, it is difficult to say by what reasoning the supreme court will reach this decision. After Walters and Hubbard it appeared that the supreme court would have to expand on the rationales offered by these cases in order to distinguish between different types of intentional conduct. Yet after Lipson it seems probable that the court may simply classify all types of intentional wrongs as independent causes of injury to which the fireman's rule is inapphicable.

This Comment rejects this classification of all intentional misconduct as imdependent causes of injury because such a classification is overly simphistic and unconvimcing. This Comment has demonstrated that the basis for the dependent/independent test comes from rationales that ignore the defendant's act and focus only on the substantive anticipations of the officer. The test offers no basis for distimguishing among different types of dependent hazards and for simgling out all intentional imisconduct as outside the scope of the fireman's rule.

Instead, this Comment suggests that the court should reconsider its analysis of the cost-spreading rationale for the fireman's rule. Specifically, the court should consider what situations the public insures itself against with its tax-supported compensation of pubhic officers and what situations workers' compensation normally covers. Since both insurance and workers' compensation statutes commonly cover both negligence and recklessness, the fireman's rule correctly reflects the legislative decision to make these injuries exclusively compensible through the statutory compensation system. On the other hand, since intentionally injurious conduct is not within the exclusive domain of workers' coinpensation, the fireman's rule should also reflect this distinction. Because the risk of injury from intentionally injurious acts is substantially greater and more difficult to prevent than are the risks posed by neghigent, reckless, or even foreseeably injurious intentional misconduct, imtentionally injurious acts are outside the scope of the public compensation system and are redressable in tort. Specifically, the cost-spreading rationale suggests that the fireman's rule should reach its limit, and not apply, in situations involving intentionally injurious conduct. Tort actions for all other dependent wrongs should be barred by the fireman's rule since they present an acceptable level of risk which has been anticipated by the statutory scheme.

This Comment accordingly proposes a comprehensive test. A court using this test should first consider whether the injury-causing hazard is dependent on or independent of the original misconduct. This determination should involve examining the job that the officer attempted to do and the subjective anticipations of the firefighter as to the likely hazards. If the cause of injury is determined to be independ- 
ent, then the fireman's rule will not apply and the wrongdoer may be held hable in tort. If the cause is dependent, however, the rule will bar civil liability unless it can be proven that the injury resulted from an intentionally injurious act.

\section{AUTHOR's POSTSCRIPT}

As this Comment went to press, the California Legislature passed, and the Governor signed into law, new subsection (a) of section 1714.9 of the Civil Code, whicls provides that one who injures a public officer or emergency medical technician is liable to that person in the following circumstances:

(2) Where the conduct causing the injury occurs after the person knows or should have known of the prcsence of the peace officer, firefighter, or einergency medical personnel, violates a statute, ordinance, or regulation, and was the proximate cause of an injury which the statute, ordinance, or regulation was designed to prevent, and the statute, ordinancc, or regnlation was designed to protect the peace officer, firefighter, or emergency inedical personnel.

As used in this subdivision, a statute, ordinance, or regulation prohibiting resistance or requiring a person to comply with an order of a peace officer or firefighter is designed to protect the peace officcr, firefighter, or einergency medical personnel.

(3) Where the conduct causing the injury was intended to injure the peace officer, firefighter, or einergency inedical personnel. 1982 Cal. Legis. Serv. 1367-68 (West).

On its face, the statute appears to do two things. Subsection (a)(3) adopts the intentionally injurious standard advocated by this Cominent, and to that extent is consistent with both prior statutory law and the analysis of this Comment. In subsection (a)(2), however, the Legislature appears to have done wliat this Comment has argued that the California courts should not do; namely, it has broadened the definition of an independent cause of injury, in this instance to include violations of statutes intended to protect public officers, by excluding such violations from the shield of the fireman's rule when they occur after the arrival of the officer. The new statute also defines protective statutes as those which prohibit resistance and disobedience to a public officer. As such, this represents a greater expansion of independent misconduct than that yet undertaken by courts. While the judicial expansion of the doctrine appears to include only intentional misconduct, the legislative response includes certain reckless acts as well. For example, reckless flight froin a pursuing police car, which Hubbard held was neither an independent risk nor a violation of a statute intended to protect public officers, is no longer shielded from liability when it re- 
sults in injury to the pursuing officer. Subsection (a)(2) of the new statute appears to provide that the statutes violated in Hubbard were enacted to protect public officers, and thus provide a civil reinedy in spite of the fireman's rule. Under both the cost-spreading rationale advanced by this Comment and prior California case law, reckless conduct of the type in Hubbard would be shielded from tort liability.

Allowing suit for injuries caused by certain types of reckless misconduct appears to be the inajor difference between the statute and this Comment in terms of what each would shield with the fireman's rule. For example, neither the new statute nor this Comment would extend the fireman's rule to shield intentionally injurious conduct. It also appears that both the statute and this Comment agree that foreseeably injurious imtentional conduct, such as arson, should be shielded by the rule. Arson neither occurs after the arrival of the firefighter nor comes within the definition of a protective statute, so subsection (a)(2) does not exclude it from the fireman's rule. And since, as this Comment has pointed out, arson alone is not intentionally mjurious conduct, subsection (a)(3) of the new statute similarly would not apply.

While it seems clear that intentionally injurious conduct will not be shielded by the fireman's rule under either the new statute or the analysis suggested by this Comment, what is left unclear is how courts will apply the new statute to reach this result. It appears that much of the misconduct which the cost-spreading rationale would exclude as dependent but intentionally injurious could now be excluded as either an independent cause of injury which violates a statute under subsection (a)(2) or an intentionally injurious injury under subsection (a)(3). Thus, under the new statute a policeman shot and wounded while answering a robbery call would have a cause of action under subsection (a)(2) because of the violation of section 245(b) of the California Penal Code, which prohibits the use of force or a weapon to resist an officer, or under subsection (a)(3) because the conduct is intentionally injurious. Of special interest, then, is how the courts will use the new statute to exclude intentionally injurious conduct.

As far as passing specific statutes which expressly protect public officers to identify misconduct which the fireman's rule cannot shield, this Comment has no argument. It is the Legislature's prerogative to identify what acts are within the fireman's rule. While this Comment has shown that the cost-spreading rationale explains the exclusion of both independent causes of injury and intentionally injurious conduct, it does not explaim either judicial or legislative labelling of violations of protective statutes as independent risks. Violations of protective statutes may be either dependent or independent misconduct. Where these violations are analytically dependent risks, neither the rationales on 
which the dependent/independent test is based nor the cost-spreading rationale suggests that the willful and reckless conduct excluded from the fireman's rule by subsection (a)(2) can be redefined as an independent cause of injury. While the power of the Legislature to identify independent risks is not open to challenge, it is the conclusion of this Comment that the Legislature, like the judiciary, is unable to broaden the definition of an independent risk in a inanner consistent with the rationales on which the dependent/independent test is based.

As argued by this Comment, the inost sound basis for excluding intentionally injurious conduct from the fireman's rule is to first admit that although the cause of injury may be the very misconduct to which the officer is responding, such misconduct is not meant to be anticipated by the publicly supported compensation systein. In this way courts can exclude intentionally injurious conduct from the fireman's rule without stretching well beyond their ineaning the rationales which determine which hazards are dependent and independent.

Benjamin K. Riley*

* A.B. 1979, Dartmouth College; third-year student, Boalt Hall School of Law, University of California, Berkeley. 